\title{
Article \\ Cytological Study of Cypripedium japonicum Thunb. (Orchidaceae Juss.): An Endangered Species from Korea
}

\author{
Bokyung Choi ${ }^{1}$, Geun-Hye Gang ${ }^{2}$, Hyeonjin Kim ${ }^{1}$, Hyejoo Byun ${ }^{1}$, Minyeong Kwak ${ }^{1}$, Soonku So ${ }^{3}$, \\ Hyeon-Ho Myeong $2, * \mathbb{D}$ and Tae-Soo Jang $1, * \mathbb{1}$
}

1 Department of Biological Science, College of Bioscience and Biotechnology, Chungnam National University, Daejeon 34134, Korea; cbokyung@cnu.ac.kr (B.C.); hyeonjin.k9924@gmail.com (H.K.); imbkbyun@gmail.com (H.B.); kmy705@naver.com (M.K.)

2 Plant Conservation Center, Korea National Park Research Institute, 2 Baengnyeonsa-gil, Seolcheon-Myeon, Muju-gun 55557, Jeollabuk-do, Korea; mama1446@knps.or.kr

3 Korea National Park Research Institute, 171 Dangu-ro, Wonju-si 26441, Gangwon-do, Korea; ssk822@knps.or.kr

* Correspondence: ecomyung@knps.or.kr (H.-H.M.); jangts@cnu.ac.kr (T.-S.J.); Tel.: +82-63-324-9120 (H.-H.M.); +82-42-821-6555 (T.-S.J.)

Citation: Choi, B.; Gang, G.-H.; Kim, H.; Byun, H.; Kwak, M.; So, S.; Myeong, H.-H.; Jang, T.-S.

Cytological Study of Cypripedium japonicum Thunb. (Orchidaceae Juss.): An Endangered Species from Korea. Plants 2021, 10, 1978. https:// doi.org/10.3390/plants10101978

Academic Editor: Tomás Naranjo

Received: 9 August 2021

Accepted: 15 September 2021

Published: 22 September 2021

Publisher's Note: MDPI stays neutral with regard to jurisdictional claims in published maps and institutional affiliations.

Copyright: (c) 2021 by the authors. Licensee MDPI, Basel, Switzerland. This article is an open access article distributed under the terms and conditions of the Creative Commons Attribution (CC BY) license (https:// creativecommons.org/licenses/by/ $4.0 /)$.

\begin{abstract}
Changes in chromosome number and karyotype evolution are important to plant diversification, as they are both major drivers of speciation processes. Herein, chromosome number, karyotype, and genome size of the Korean lady's slipper orchid Cypripedium japonicum Thunb., an endangered species, were investigated in natural populations. Furthermore, all cytological data from this species are reported herein for the first time. The chromosome number of all investigated C. japonicum plants was diploid $(2 n=2 x=22)$, with $x=11$ as base chromosome number, whereby the species can now be clearly distinguished from the Japanese lady's slipper orchid. The karyotypes of all studied individuals were of similar length, symmetrical, and rather unimodal. Flow cytometry of the $C$. japonicum revealed that the genome size ranged from 28.38 to $30.14 \mathrm{pg} / 1 \mathrm{C}$. Data on chromosome number and karyotypes were largely consistent with previous results indicating that Korean $(x=11)$ populations of $C$. japonicum are more closely related to Chinese populations $(x=11)$ compared to Japanese $(x=10)$ populations. These comprehensive cytological results will benefit the efforts to discriminate the geographically isolated and endangered Eastern Asian (China, Japan, and Korea) lady's slipper orchid species.
\end{abstract}

Keywords: Cypripedium japonicum; endangered species; haploid chromosome number; karyotype; genome size

\section{Introduction}

The genus Cypripedium L. (Orchidaceae Juss.) comprises approximately 50 species of terrestrial herbs primarily distributed in the temperate regions of the northern hemisphere, including Asia and North America [1]. Cypripedium japonicum Thunb., commonly known as lady's slipper orchid, is a rare to extremely rare perennial herb found across East Asia (China, Japan, and Korea) [2-7]. The species is characterized by having a large and attractive flower and two subopposite fan-shaped leaves [1,5]. The species has been globally categorized as endangered based on the International Union for Conservation of Nature (IUCN) Red List of Threatened Species [2], and it is nationally listed as vulnerable in Japan [4] and critically endangered in Korea, respectively [3,5]. The species is increasingly becoming rare due to over-collection/over-exploitation from its natural habitats for horticultural and medicinal purposes [2-5], and protection and conservation of natural individuals / populations of C. japonicum is crucial both locally and globally [2-4]. Despite the increasing importance of the conservation status, biological studies of the Cypripedium species have been focused on population genetics $[5,6,8]$, pollination biology [9] 
and reproductive characteristics [7], and no comprehensive cytological analyses have been performed to date for this orchid. The genus Cypripedium has two base chromosome numbers: $x=10(2 n=20$ and 30$)$ and $11(2 n=22)$, with the most frequently encountered chromosome number being $2 n=20$ in Cypripedium species $[10,11]$. In C. japonicum, diploids were reported from Japanese $(2 n=20 ;[10,12,13])$ and Chinese populations $(2 n=22 ;[14])$ with different base chromosome numbers. To date, however, no chromosome number and karyotype data of $C$. japonicum from Korean populations are available.

Changes in chromosome number (aneuploidy/dysploidy or polyploidy) and structure (inversions, translocations, additions, deletions) play a crucial role in plant evolution and diversification [15-17]. Cytological research, including karyotype analysis and genome size estimation, is considered as an important and useful approach in evolutionary studies of angiosperms [18-24]. Previously published genome size values within genus Cypripedium showed a 10.83 -fold difference, ranging from $4.14 \mathrm{pg} / 1 \mathrm{C}$ in $\mathrm{C}$. molle to $44.84 \mathrm{pg} / 1 \mathrm{C}$ in C. acaule [24]. However, to date, nuclear DNA content data of Cypripedium species assessed using flow cytometry analysis are available only for nine species out of fifty species in total, and it is still not available for C. japonicum [24]. As chromosome number, karyotype structure, and genome size data have been proved highly informative taxonomicallyparticularly within the Cypripedium genus [10,12-14] — these data should be obtained from natural populations of Korean lady's slipper orchids.

Thus, the goals of this study were: (1) to establish the chromosome number and the haploid chromosome-size variation as well as the karyotype structure of $C$. japonicum from multiple natural populations in Korea; and (2) to provide data on the C-value to reveal possible patterns of variation in genome size for this species.

\section{Materials and Methods}

\subsection{Cytological Analysis}

Young flower buds from 11 individuals were collected from 5 natural populations of Cypripedium japonicum Thunb. (Table 1; Figure 1) with special permission from the Korean Government (permit no. 2021-17 and 2021-18). Pollinia, including numerous pollen grains, is a specific characteristic of the Orchidaceae family [25], and thus chromosome numbers were determined from meiotic cell divisions in pollen mother cells of pollinia due to the lack of typical root meristems in C. japonicum (Figure 1C). The samples were immediately fixed in freshly prepared fixative (3:1 ethanol: acetic acid) and stored at $-20{ }^{\circ} \mathrm{C}$ until subsequent use. Chromosome numbers were determined using the standard Feulgen staining technique according to Choi et al. [20]. In brief, young pollinia of flower buds were hydrolyzed in $5 \mathrm{~N} \mathrm{HCl}$ at $25^{\circ} \mathrm{C}$ for $30 \mathrm{~min}$ and immediately stained with Schiff's reagent (Merck KGaA, Darmstadt, Germany) for $60 \mathrm{~min}$. Squash preparations were made in a drop of $60 \%$ acetic acid. At least five well-spread chromosome plates were analyzed for each individual using a light microscope (Olympus BX-53, Tokyo, Japan) and photographed using a digital camera (Olympus DP-74, Tokyo, Japan), following the method by Choi et al. [21]. A minimum of three well-spread chromosome plates was selected for karyotype analysis and chromosome-size measurement [23]. 
Table 1. Plant material used for cytogenetic analyses in Cypripedium japonicum.

\section{Collection Number (Population_Individual)}

DY1_1
DY1_2
DY1_3
DY1_4
DY1_5
DY1_6
DY2_1
DY2_2
DY2_3
DY2_4
DY2_5
DY3_1
YD_1
YD_2
YD_3
YD_4
YD_5
HC_1
HC_2
HC_3

\section{Locality; Collector}

Mt. Deokyu, Muju-gun, Jeollabuk-do; MHH

Mt. Deokyu, Muju-gun, Jeollabuk-do; $\mathrm{MHH}$

Mt. Deokyu, Muju-gun, Jeollabuk-do; $\mathrm{MHH}$

Mt. Deokyu, Muju-gun, Jeollabuk-do; MHH

Mt. Deokyu, Muju-gun, Jeollabuk-do; MHH

Mt. Deokyu, Muju-gun, Jeollabuk-do; MHH

Mt. Deokyu, Muju-gun, Jeollabuk-do; $\mathrm{MHH}$

Mt. Deokyu, Muju-gun, Jeollabuk-do; MHH

Mt. Deokyu, Muju-gun, Jeollabuk-do; $\mathrm{MHH}$

Mt. Deokyu, Muju-gun, Jeollabuk-do; $\mathrm{MHH}$

Mt. Deokyu, Muju-gun, Jeollabuk-do; MHH

Mt. Deokyu, Muju-gun, Jeollabuk-do; TSJ

Youngdong-gun, Chungcheongbuk-do; $\mathrm{MHH}$

Youngdong-gun, Chungcheongbuk-do; $\mathrm{MHH}$

Youngdong-gun, Chungcheongbuk-do; $\mathrm{MHH}$

Youngdong-gun, Chungcheongbuk-do; $\mathrm{MHH}$

Youngdong-gun, Chungcheongbuk-do; $\mathrm{MHH}$

Hwacheon-gun, Gangwon-do; $\mathrm{MHH}$

Hwacheon-gun, Gangwon-do; MHH

Hwacheon-gun, Gangwon-do; MHH

\section{Chromosome Number}

$$
\begin{aligned}
2 n & =22 \\
& - \\
& - \\
& - \\
2 n & =22 \\
2 n & =22 \\
& - \\
2 n & =22 \\
2 n & =22 \\
2 n & =22 \\
& - \\
2 n & =22 \\
2 n & =22 \\
2 n & =22 \\
& - \\
& - \\
& - \\
2 n & =22 \\
2 n & =22
\end{aligned}
$$

$$
-
$$

Genome Size

\section{$1 C \pm$ S.D. $(\mathrm{pg})$}

$29.58+0.59$

$29.27 \pm 0.49$

$29.59 \pm 0.35$

$29.86 \pm 0.23$

$29.99 \pm 0.49$

$29.97 \pm 0.05$

$29.47 \pm 0.09$

$28.77 \pm 0.65$

$28.39 \pm 0.33$

$29.43 \pm 0.39$

$29.94 \pm 0.85$

$29.31 \pm 0.44$

$29.20 \pm 0.98$

$28.38 \pm 0.38$

$29.48 \pm 0.49$

$28.26 \pm 0.45$

$30.14 \pm 0.11$

$29.29 \pm 0.68$

$28.73 \pm 0.31$

$29.59 \pm 0.33$

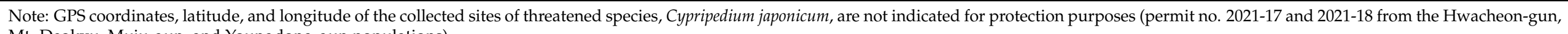
Mt. Deokyu, Muju-gun, and Youngdong-gun populations) 

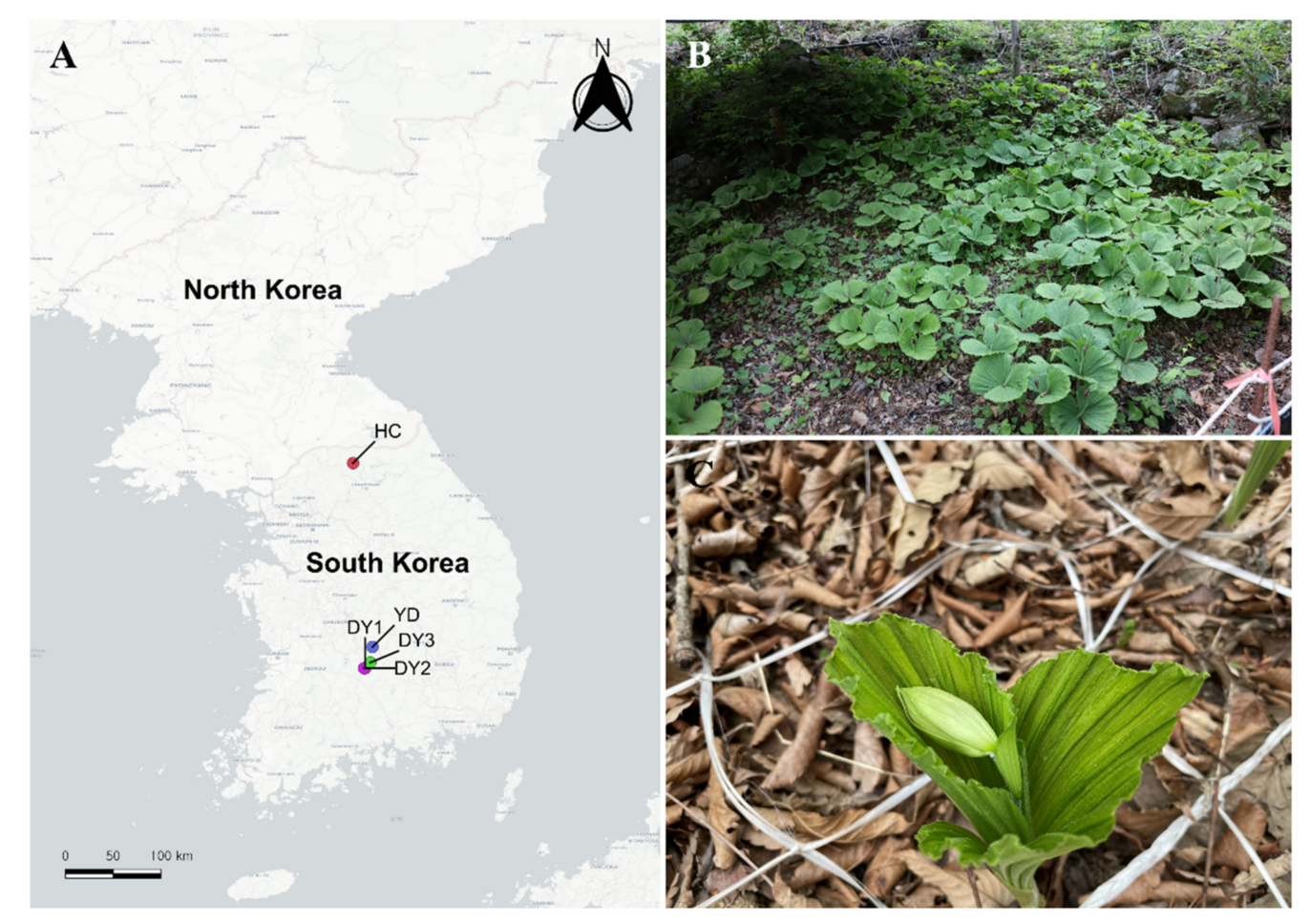

Figure 1. Sampled populations of Cypripedium japonicum in Korea (A), DY1, DY2, and DY3 (Mt. Deokyu population), YD (Youngdong-gun population), HC (Hwacheon-gun population), detailed information is given in Table 1. (B) Natural habitat of Hwacheon-gun population (HC), (C) Habit, unopened flower bud for meiotic analysis.

\subsection{Genome Size Measurement}

The genome size of 20 individual C. japonicum plants was determined by flow cytometry with Vicia faba L. "Inovec" $(13.45 \mathrm{pg} / 1 \mathrm{C})$ as an internal reference standard [26,27]. Approximately 20-30 mg of fresh leaves from each sample were co-chopped with an internal reference standard using Otto's buffer I [28], and isolated nuclei were stained using propidium iodide with RNase IIA (both at $50 \mu \mathrm{g} / \mathrm{mL}$ ) solution for $5 \mathrm{~min}$ at $25^{\circ} \mathrm{C}$, and analyzed using a Sysmex CyFlow cytometer (Sysmex Partec GmbH, Görlitz, Germany). The methodology used for the measurement of the genome size was as described by Choi et al. [22]. The 1C value was calculated as indicated by Doležel et al. [27]: sample peak mean/standard peak mean $\times 1 \mathrm{C}$ DNA content of standard $(\mathrm{pg})$. Genome size measurements were performed in triplicate for each $C$. japonicum individual.

\section{Results and Discussion}

\subsection{Chromosome Numbers and Karyotype Structure of Cypripedium japonicum Thunb.}

The chromosome number and the karyotype of Korean populations of $C$. japonicum, the endangered Korean lady's slipper orchid, are reported here for the first time (Tables 1 and 2; Figures 1 and 2). The 11 individuals (sampled from five populations) were all diploids with $n=11$ ( $2 n=22$; Figure 2A,B,D,E), as previously reported for Chinese populations [12], although $n=10(2 n=20)$ was also found by several studies from Japan $[10,12,13]$.

The representative karyotypes with detailed chromosome size are presented in Figure 2D-E and Table 3. No meiotic abnormalities, such as laggards or bridges during cell divisions, were found in any of the analyzed C. japonicum individuals (Figure 2C). 
Table 2. New and previously published chromosome counting $(2 n)$ and genome size $(1 \mathrm{C} / \mathrm{pg})$ data in the genus Cypripedium.

\begin{tabular}{|c|c|c|c|c|}
\hline Taxon & $2 n$ & References & $1 C(p g)$ & References \\
\hline Cypripedium acaule Aiton & 20 & [11] & 44.84 & [24] \\
\hline C. arietinum R.Br. & 20 & [11] & - & - \\
\hline \multirow[t]{2}{*}{ C. calceolus L. } & 20 & [11] & 32.35 & [24] \\
\hline & & & 41.05 & [29] \\
\hline C. californicum A.Gray & 20 & [30] & 21.60 & [30] \\
\hline C. candidum Muhl. ex Willd. & 20 & [11] & - & - \\
\hline C. cordigerum D.Don & 20 & [31] & - & - \\
\hline C. debile Rchb. & 20 & [32] & - & - \\
\hline C. elegans Rchb. & 20 & [11] & - & - \\
\hline C. fasciculatum kellogg & 20 & [11] & - & - \\
\hline C. flavum P.F.Hunt and Summerh. & 20 & [11] & 36.41 & [33] \\
\hline C. formosanum Hayata & 20,30 & [10] & $28.50,32.00$ & [24] \\
\hline C. guttatum Sw. & 20 & [11] & - & - \\
\hline C. henryi Rolfe & 22 & [32] & 38.80 & [24] \\
\hline C. himalaicum Rolfe & 20,30 & [11] & - & - \\
\hline $\begin{array}{l}\text { C. japonicum Thunb. } \\
\text { (population in Japan) }\end{array}$ & 20 & {$[10]$} & - & - \\
\hline $\begin{array}{l}\text { C. japonicum Thunb. } \\
\text { (population in Korea and China) }\end{array}$ & 22 & [12], Present study & $28.38-30.14$ & Present study \\
\hline C. macranthos Sw. & 20,22 & [11] & 37.40 & [24] \\
\hline C. molle Lindl. & 20 & {$[11]$} & 4.14 & {$[24]$} \\
\hline C. parviflorum Salisb. & 20 & {$[11]$} & - & - \\
\hline C. parviflorum var. makasin (Farw.) Sheviak & 20 & [11] & - & - \\
\hline $\begin{array}{l}\text { C. parviflorum var. pubescens (Willd.) O. W. } \\
\text { Knight }\end{array}$ & 20 & [30] & 32.40 & [30] \\
\hline C. passerinum Richardson & 20 & [11] & - & - \\
\hline C. plectrochilum Franch. & 20 & [11] & - & - \\
\hline C. reginae Walter & 20 & [11] & - & - \\
\hline C. segawae Masam. & 20 & [10] & - & - \\
\hline C. shanxiense S.C.Chen & 20 & [11] & - & - \\
\hline C. tibeticum King ex Rolfe & 20 & [32] & - & - \\
\hline C. yatabeanum Makino & 20 & {$[10]$} & - & - \\
\hline
\end{tabular}
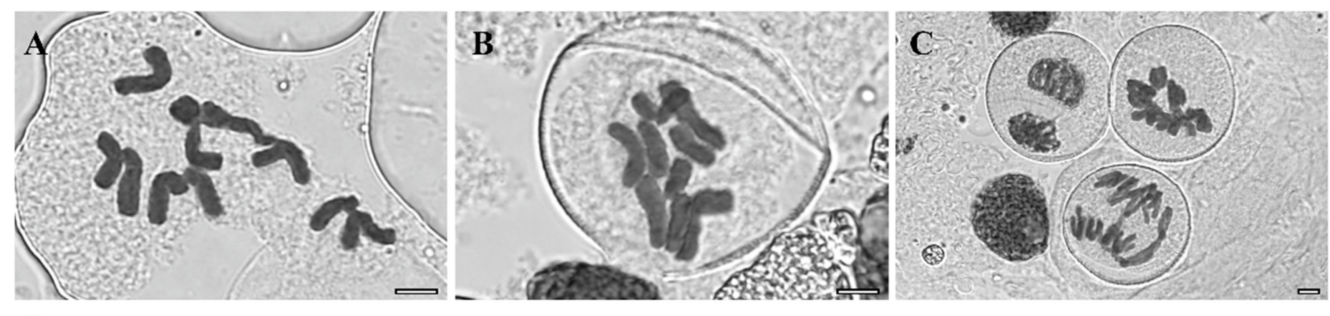

D
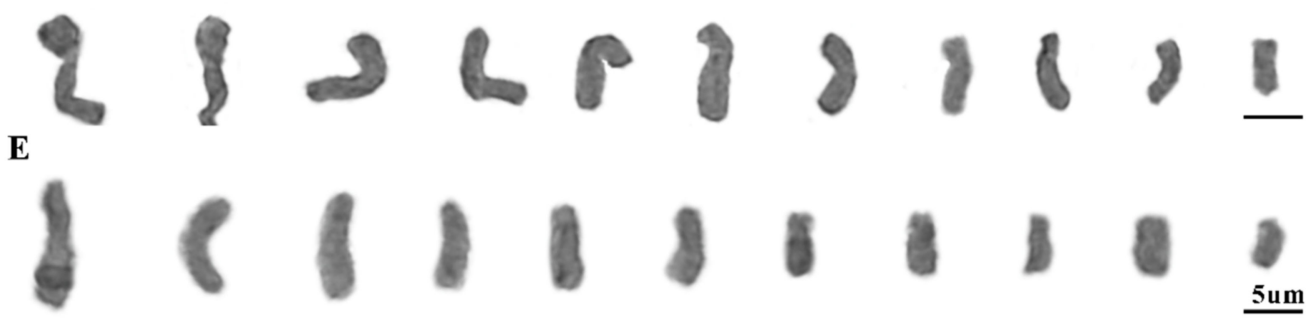

Figure 2. Meiotic chromosomes and karyotypes of Cypripedium japonicum. (A,C,D) collection number (population_individual): DY1_5, (B,E) collection number (population_individual): DY2_2, detailed information is given in Table 1. 
Table 3. Karyotype analyses in the Korean endangered species, Cypripedium japonicum.

\begin{tabular}{|c|c|c|c|c|c|c|c|c|c|c|c|c|c|c|}
\hline \multirow{2}{*}{$\begin{array}{c}\text { Collection Number } \\
\text { (Population_Individual) }\end{array}$} & \multicolumn{11}{|c|}{ Absolute Chromosome Length $(\mu \mathrm{m})$} & \multirow{2}{*}{$\mathrm{HCL}^{1} \pm$ S.D. $(\mu \mathrm{m})$} & \multirow{2}{*}{$\operatorname{AsI}^{2}(\%)$} & \multirow{2}{*}{$\mathrm{RI}^{3}$} \\
\hline & 1 & 2 & 3 & 4 & 5 & 6 & 7 & 8 & 9 & 10 & 11 & & & \\
\hline DY1_1 & 14.57 & 13.49 & 12.47 & 9.94 & 9.81 & 9.31 & 8.67 & 7.71 & 6.27 & 5.25 & 4.58 & $102.07 \pm 3.27$ & 66.7 & 1.69 \\
\hline DY1_5 & 12.33 & 10.26 & 9.38 & 9.00 & 8.25 & 7.86 & 7.30 & 7.11 & 6.47 & 4.94 & 4.26 & $87.04 \pm 2.30$ & 59.9 & 1.84 \\
\hline DY2_2 & 12.52 & 10.69 & 9.28 & 9.43 & 8.27 & 6.78 & 8.56 & 7.31 & 6.22 & 5.38 & 4.72 & $89.16 \pm 2.33$ & 61.9 & 3.51 \\
\hline
\end{tabular}

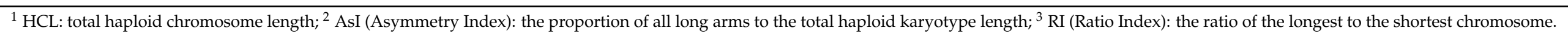


The previously reported base chromosome number for Cypripedium was constant $(x=10)$, with diploids being the most common among the species followed by triploids (Table 2; [29-33]), except for C. macranthos that presents $2 n=22$ [11]. The Chinese and Korean populations of $C$. japonicum clearly showed $2 n=22(n=11$; Figure $2 \mathrm{D}-\mathrm{E}$; [14]), whereas those from the Japanese populations had $2 n=20$ (Table 2; $[10,12,13]$ ). In Cypripedium, C. japonicum and $C$. macranthos had two base chromosome numbers, and this was not found in the rest of the Cypripedium species studied to date (Table 2). The difference in base chromosome number between Chinese-Korean $(x=11)$ and Japanese $(x=10)$ populations strongly indicated that the Korean populations of $C$. japonicum are more closely related to Chinese populations compared to the Japanese populations based on base chromosome numbers, and this result was consistent with population genetic analyses using ISSR and SCoT markers [5,6]. Thus, further studies, including physical mapping of chromosomes using FISH (fluorescence in situ hybridization) as well as molecular phylogenomics and population genomics of $C$. japonicum and its closely related species, could help clarify the evolutionary history of C. japonicum [19,34-40].

The karyotypes of the C. japonicum individuals investigated herein were all very similar, containing meta- and submetacentric chromosomes (Figure 2D-E). The total haploid length of chromosomes ranged from $87.04 \mu \mathrm{m}$ (accession number: DY1_5) to $102.07 \mu \mathrm{m}$ (accession number: DY1_1). Concomitantly, individual chromosome lengths ranged from 4.26 to $4.58 \mu \mathrm{m}$ in the shortest and from 12.33 to $14.57 \mu \mathrm{m}$ in the longest chromosomes (Table 3). The ratio of the longest to shortest chromosome (RI) ranged from 1.69 to 3.51, with a similar asymmetry index (59.9-66.7\%; Table 3).

Karyotype analysis relies on the identification of individual chromosomes and has been a challenge for most non-model plants, especially while conducting direct comparisons for chromosome size and karyotype formula among related species $[17,22,34]$. The newly counted chromosomes and karyotypes for Korean endangered lady's slipper orchids presented here are against the deviating counts of $2 n=22(14 \mathrm{~m}+6 \mathrm{sm})$ from Japanese populations [13], implying the likely involvement of dysploidy or aneuploid numbers. However, karyotypes in the data reported herein were constant among populations, as previously observed in Chinese populations [14] and as suggested by the lack of genetic variation either within or among populations of C. japonicum in Korea [5,6].

\subsection{Genome Size Estimation in Korean C. japonicum}

The 1C DNA contents of the investigated plants are shown in Table 1 and Figure 3, which are reported in this study for the first time. DNA content analysis revealed welldefined peaks for all samples (Figure 3A,B). As measured by flow cytometry using propidium iodide, the genome size of the analyzed $C$. japonicum individuals ranged from $28.38 \mathrm{pg} / 1 \mathrm{C}$ to $30.14 \mathrm{pg} / 1 \mathrm{C}$ (Table 1; Figure 3C). The C-values within the genus Cypripedium have been reported ranging from $4.14 \mathrm{pg} / 1 \mathrm{C}$ in $C$. molle to $44.84 \mathrm{pg} / 1 \mathrm{C}$ in $C$. acaule, in spite of which, they all had the same chromosome number, $2 n=2 x=20$ (Table 2; [22]). The underlying reason for genome size differences among the Cypripedium species might be the differential accumulation of non-coding repetitive DNAs, as reported in other plant groups (Figure 3C; $[19,40,41])$. An understanding of chromosomal variation among populations concomitant with changes in genome size may provide novel insights into the ecological conservation status for the extremely endangered/threatened taxa, as reported for other genera of Orchidaceae [30,42,43]. 


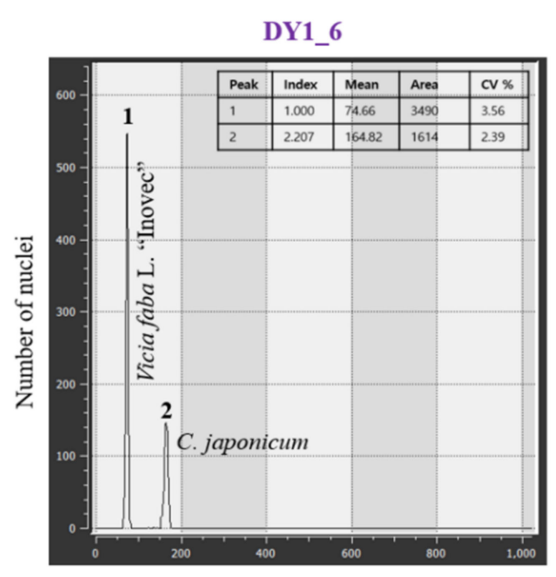

(A)

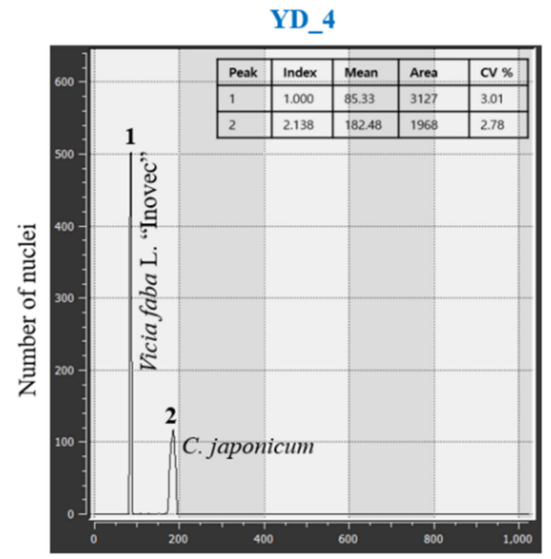

(B)

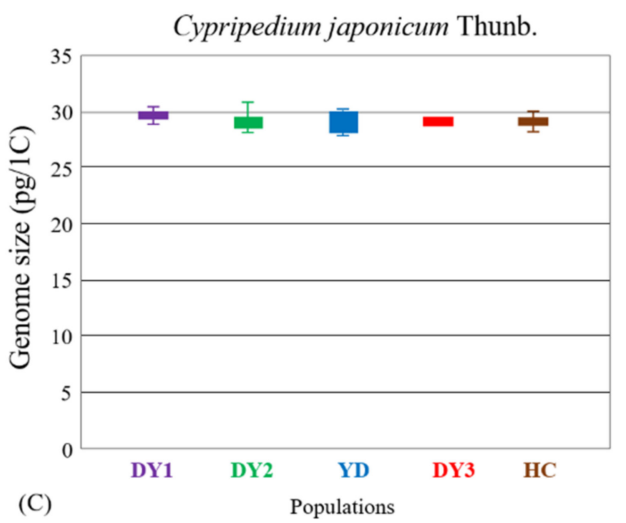

Figure 3. Fluorescence histogram results of Cypripedium japonicum with an internal reference standard (Vicia faba L. "Inovec": 13.45 pg/1C). (A) DY1_6 (population_individual; Mt. Deokyu population), (B) YD_4 (population_individual; Youngdong-gun population), (C) Distribution of genome size data $[1 \mathrm{C}(\mathrm{pg})]$ in the investigated five natural populations. Detailed population information is given in Table 1.

\section{Conclusions}

This study presents the first comprehensive cytological analysis of meiotic chromosome number, karyotype, and nuclear DNA content of the endangered orchid C. japonicum from multiple Korean populations. In light of our results, the data on chromosome numbers and karyotypes are largely consistent with the previous population genetic study indicating that Korean populations $(x=11)$ of $C$. japonicum are more closely related to Chinese populations $(x=11)$ than they are to Japanese $(x=10)$ populations. The cytogenetic study can be beneficial to the discrimination of geographically isolated Eastern Asian (China, Japan, and Korea) endangered lady's slipper orchids, and provide biological background for conservation. To protect and enhance the conservation status of this endangered species, further molecular cytogenetic and phylogenomic studies, including DNA sequencing based on additional population genetic markers, are needed using a larger number of individuals from multiple populations of East Asian orchids.

Author Contributions: Conceptualization, B.C., T.-S.J. and H.-H.M.; Collection and identification of plant material, B.C., G.-H.G., S.S., H.-H.M. and T.-S.J.; Methodology, B.C., H.K., M.K., H.B. and T.-S.J.; Formal analysis, B.C. and T.-S.J.; Writing-original draft preparation, B.C. and T.-S.J.; Writing-review and editing, B.C. and T.-S.J.; Visualization, B.C. and T.-S.J.; Supervision, T.-S.J.; Project administration, T.-S.J. and H.-H.M.; Funding acquisition, T.-S.J. and H.-H.M. All authors have read and agreed to the published version of the manuscript. 
Funding: This work was funded by the National Research Foundation of Korea (NRF), grant number 2021R1I1A2045820 to T.-S. Jang and grants from the Korea National Park Research Institute, grant number NPRI 2021 to H.-H. Myeong.

Institutional Review Board Statement: Not applicable.

Informed Consent Statement: Not applicable.

Data Availability Statement: The data presented in this study will be available on request from the corresponding authors.

Acknowledgments: The authors would like to thank Jaroslav Doležel (Institute of Experimental Botany, Olomouc, Czech Republic) for the kind provision of seeds for reference standard for the genome size measurements. We are also grateful for the lab members at CNUK (The Herbarium of Chungnam National University) who helped us in various ways.

Conflicts of Interest: The authors declare no conflict of interest.

\section{References}

1. Chen, X.C.; Zhu, G.H.; Ji, Z.H.; Lang, K.Y.; Luo, Y.B.; Cribb, P. Orchidaceae. In Flora of China; Wu, Z.Y., Raven, P.H., Eds.; Science Press: Beijing, China; Missouri Botanical Garden: St. Louis, MO, USA, 2005; Volume 25, pp. 19-72.

2. Rankou, H. Cypripedium japonicum. The IUCN Red List of Threatened Species 2014: eT13188414A1667285. Available online: http:/ / dx.doi.org/10.2305/IUCN.UK.2014-1.RLTS.T13188414A16672875.en (accessed on 14 September 2021).

3. Cho, Y.C.; Kim, H.G.; Koo, B.Y.; Shin, J.K. Dynamics and viability analysis of transplanted and natural lady's slipper (Cypripedium japonicum) populations under habitat management in South Korea. Restor. Ecol. 2019, 27, 23-30. [CrossRef]

4. Ministry of the Environment. Threatened Wildlife of Japan, Red Data Book 2014: Vascular Plants; Gyosei: Tokyo, Japan, 2015; Volume 8. (In Japanese)

5. $\quad$ Chung, J.M.; Park, K.W.; Park, C.-S.; Lee, S.-H.; Chung, M.G.; Chung, M.Y. Contrasting levels of genetic diversity between the historically rare orchid Cypripedium japonicum and the historically common orchid Cypripedium macranthos in South Korea. Bot. J. Linn. Soc. 2009, 160, 119-129. [CrossRef]

6. Tian, H.Z.; Han, L.; Zhang, J.L.; Li, X.L.; Kawahara, T.; Yukawa, T.; López-Pujol, J.; Kumar, P.; Chung, M.G.; Chung, M.Y. Genetic diversity in the endangered terrestrial orchid Cypripedium japonicum in East Asia: Insights into population history and implications for conservation. Sci. Rep. 2018, 8, 6467. [CrossRef]

7. Ghimire, B.; Son, S.; Kim, J.H.; Jeong, M.J. Gametophyte and embryonic ontogeny: Understanding the reproductive calendar of Cypripedium japonicum Thunb. (Cypripedoideae, Orchidaceae), a lady's slipper orchid endemic to East Asia. BMC Plant Biol. 2020, 20, 426. [CrossRef] [PubMed]

8. Qian, X.; Li, Q.-J.; Liu, F.; Gong, M.-J.; Wang, C.-X.; Tian, M. Conservation genetics of an endangered lady's slipper orchid: Cypripedium japonicum in China. Int. J. Mol. Sci. 2014, 15, 11578-11596. [CrossRef]

9. Suetsugu, K.; Fukushima, S. Pollination biology of the endangered orchid Cypripedium japonicum in a fragmented forest of Japan. Plant Species Biol. 2014, 29, 294-299. [CrossRef]

10. Karasawa, K.; Aoyama, M. Karyomorphological studies on Cypripedium in Japan and Formosa. Bull. Hiroshima Bot. Gard. 1986, 8 , 1-22. (In Japanese)

11. Rice, A.; Glick, L.; Abadi, S.; Einhorn, M.; Kopelman, N.M.; Salman-Minkov, A.; Mayzel, J.; Chay, O.; Mayrose, I. The chromosome counts database (CCDB)-A community resource of plant chromosome numbers. New Phytol. 2015, 206, 19-26. [CrossRef]

12. Tanaka, R. Chromosome numbers of some species of Orchidaceae from Japan and its neighbouring areas. J. Jpn. Bot. 1965, $40,65-77$.

13. Kondo, K.; Hoshi, Y.; Tanaka, R. Somatic chromosome differentiation in Cypripedium segawai Masamune and C. japonicum Thunberg. Cytologia 1994, 59, 115-120. [CrossRef]

14. Qian, X.; Lian, J.J.; Li, Q.J.; Liu, F.; Wang, C.X.; Tian, M. Karyotype Analysis of Cypripedium japonicum Thunb. and Calanthe tsoongiana T. Tang et F. T. Wang. J. Trop. Subtrop. Bot. 2013, 21, 414-419.

15. Schubert, I. Chromosome evolution. Curr. Opin. Plant Biol. 2007, 10, 109-115. [CrossRef]

16. Guerra, M. Chromosome numbers in plant cytotaxonomy: Concepts and implications. Cytogenet. Genome Res. 2008, 120, 339-350. [CrossRef] [PubMed]

17. Weiss-Schneeweiss, H.; Schneeweiss, G.M. Karyotype diversity and evolutionary trends in angiosperms. In Plant Genome Diversity 2: Physical Structure, Behaviour and Evolution of Plant Genomes; Springer: Vienna, Austria, 2013; Volume 2, pp. $209-230$.

18. Siljak-Yakovlev, S.; Pustahija, F.; Šolić, E.M.; Bogunić, F.; Muratović, E.; Bašić, N.; Catrice, O.; Brown, S.C. Towards a genome size and chromosome number database of Balkan Flora: C-values in 343 taxa with novel values for 242. Adv. Sci. Lett. 2010, 3 , 190-213. [CrossRef]

19. Jang, T.-S.; Parker, J.S.; Emadzade, K.; Temsch, E.M.; Leitch, A.R.; Weiss-Schneeweiss, H. Multiple origins and nested cycles of hybridization result in high tetraploid diversity in the monocot Prospero. Front. Plant Sci. 2018, 9, 433. [CrossRef] [PubMed] 
20. Choi, B.; Yang, S.; Song, J.-H.; Jang, T.-S. Karyotype and genome size variation in Ajuga L. (Ajugoideae-Lamiaceae). Nord. J. Bot. 2019, 37, e02337. [CrossRef]

21. Choi, B.; Jang, T.-S.; Park, J.-M.; Kim, J.H.; Sim, S.; Hyun, C.W.; Kim, S.; Park, M.S.; Na, N.; Kim, D.K. Cytotaxonomy of endangered species Orobanche filicicola in Korea and its closely related species, Orobanche coerulescens (Orobanchaceae) (I). J. Asia-Pac. Biodivers. 2020, 13, 438-442. [CrossRef]

22. Choi, B.; Weiss-Schneeweiss, H.; Temsch, E.M.; So, S.; Myeong, H.-H.; Jang, T.-S. Genome size and chromosome number evolution in Korean Iris L. species (Iridaceae Juss.). Plants 2020, 9, 1284. [CrossRef]

23. Choi, B.; Kim, S.-Y.; Jang, T.-S. Micromorphological and cytological comparisons between Youngia japonica and Youngia longiflora using light and scanning electron microscopy. Microsc. Res. Tech. 2020, 83, 1456-1463. [CrossRef]

24. Pellicer, J.; Leitch, I.J. The plant DNA C-values database (release 7.1): An updated online repository of plant genome size data for comparative studies. New Phytol. 2020, 226, 301-305. [CrossRef]

25. Pacini, E.; Hesse, M. Types of pollen dispersal units in orchids, and their consequences for germination and fertilization. Ann. Bot. 2002, 89, 653-664. [CrossRef]

26. Doležel, J.; Sgorbati, S.; Lucretti, S. Comparison of three DNA fluorochromes for flow-cytometric estimation of nuclear DNA content in plants. Physiol. Plant. 1992, 85, 625-631. [CrossRef]

27. Doležel, J.; Greilhuber, J.; Suda, J. Estimation of nuclear DNA content in plants using flow cytometry. Nat. Protoc. 2007, 2, 2233-2244. [CrossRef] [PubMed]

28. Otto, F.; Oldiges, H.; Gohde, W.; Janin, V.K. Flow cytometric measurement of nuclear DNA content variations as a potential in vivo mutagenicity test. Cytometry 1981, 2, 189-191. [CrossRef]

29. Rewers, M.; Jedrzejczyk, I.; Rewicz, A.; Jakubska-Busse, A. Genome size diversity in rare, endangered, and protected orchids in Poland. Genes 2021, 12, 563. [CrossRef] [PubMed]

30. Cox, A.V.; Abdelnour, G.J.; Bennett, M.D.; Leitch, I.J. Genome size and karyotype evolution in the slipper orchids (Cypripedioideae: Orchidaceae). Am. J. Bot. 1998, 85, 681-687. [CrossRef]

31. Vij, S.P.; Mehra, P.N. Cytological studies in the East Himalayan Orchidaceae. III. Cypripedieae. Caryologia 1974, 27, 293-300. [CrossRef]

32. Hoshi, Y.; Kondo, K.; Tanaka, R.; Karasawa, K. A comparison of C-banding in nine species of Cypripedium (Orchidaceae). Kromosomo 1995, 77, 2636-2645.

33. Veselý, P.; Bureš, P.; Šmarda, P.; Pavlíček, T. Genome size and DNA base composition of geophytes: The mirror of phenology and ecology? Ann. Bot. 2011, 109, 65-75. [CrossRef] [PubMed]

34. Jang, T.-S.; McCann, J.; Parker, J.S.; Takayama, K.; Hong, S.-P.; Schneeweiss, G.M.; Weiss-Schneeweiss, H. rDNA loci evolution in the genus Glechoma (Lamiaceae). PLoS ONE 2016, 11, e0167177. [CrossRef]

35. Mandáková, T.; Pouch, M.; Harmanová, K.; Zhan, S.H.; Mayrose, I.; Lysak, M.A. Multispeed genome diploidization and diversification after an ancient allopolyploidization. Mol. Ecol. 2017, 26, 6445-6462. [CrossRef]

36. Waminal, N.E.; Pellerin, R.J.; Kang, S.-H.; Kim, H.H. Chromosomal mapping of tandem repeats revealed massive chromosomal rearrangements and insights into Senna tora dysploidy. Front. Plant Sci. 2021, 12, 629898. [CrossRef]

37. Dodsworth, S.; Jang, T.-S.; Struebig, M.; Chase, M.W.; Weiss-Schneeweiss, H.; Leitch, A.R. Genome-wide repeat dynamics reflect phylogenetic distance in closely related allotetraploid Nicotiana (Solanaceae). Plant Syst. Evol. 2017, 303, 1013-1020. [CrossRef] [PubMed]

38. Chiarini, F.; Moreno, N.; Moré, M.; Barboza, G. Chromosomal changes and recent diversification in the Andean genus Jaborosa (Solanaceae). Bot. J. Linn. Soc. 2017, 183, 57-74.

39. Li, X.; Jang, T.-S.; Temsch, E.M.; Kato, H.; Takayama, K.; Schneeweiss, G.M. Molecular and karyological data confirm that the enigmatic genus Platypholis from Bonin-Islands (SE Japan) is phylogenetically nested within Orobanche (Orobanchaceae). J. Plant Res. 2017, 130, 273-280. [CrossRef]

40. Emadzade, K.; Jang, T.-S.; Macas, J.; Kovařík, A.; Novák, P.; Parker, J.; Weiss-Schneeweiss, H. Differential amplification of satellite PaB6 in chromosomally hypervariable Prospero autumnale complex (Hyacinthaceae). Ann. Bot. 2014, 114, 1597-1608. [CrossRef]

41. Weiss-Schneeweiss, H.; Leitch, A.R.; McCann, J.; Jang, T.-S.; Macas, J. Employing next generation sequencing to explore the repeat landscape of the plant genome. In Next Generation Sequencing in Plant Systematics; Regnum Vegetabile 157; Koeltz Scientific Books: Königstein, Germnay, 2015; Volume 158, pp. 155-179.

42. Pinheiro, F.; Cozzolino, S. Epidendrum (Orchidaceae) as a model system for ecological and evolutionary studies in the Neotropics. Taxon 2013, 62, 77-88. [CrossRef]

43. Zeng, R.-Z.; Zhu, J.; Xu, S.-Y.; Du, G.-H.; Guo, H.-R.; Chen, J.; Zhang, Z.-S.; Xie, L. Unreduced male gamete formation in Cymbidium and its use for developing sexual polyploid cultivars. Front. Plant Sci. 2020, 11, 558. [CrossRef] [PubMed] 